\title{
A TRANSPORTABLE FORM OF STANDARD CELL.
}

By Ralph E. DeLury.

THE ordinary or $\mathrm{H}$-form of cell and also its modification, the $\Lambda$-form, possess the disadvantage that they are not transportable. Rough handling will cause the contents of the two legs to mix thus destroying the cell as a standard. In the cell described below, the contents cannot mix even though the cell be inverted or shaken. A glance at Fig. 2 will show the shape of the cell. It may be made as follows:

Take a piece of tubing $A$, Fig. I, of suitable thickness, I 5 or 20 $\mathrm{cm}$. long and $\mathrm{I} .5$ to $2.5 \mathrm{~cm}$. in diameter. Take another piece $B$,

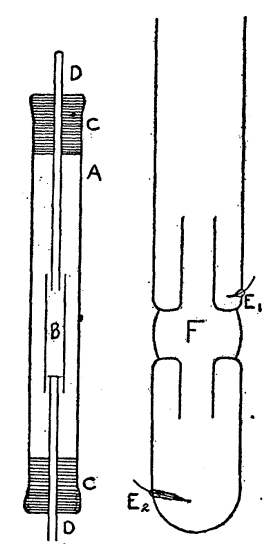

Fig. 1.

Fig. 2.

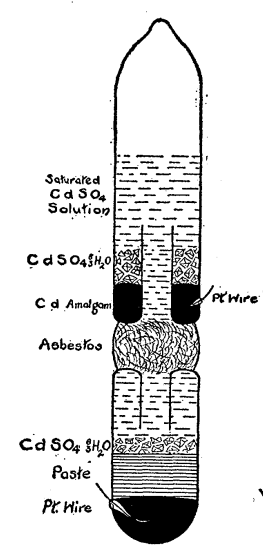

Fig. 3.

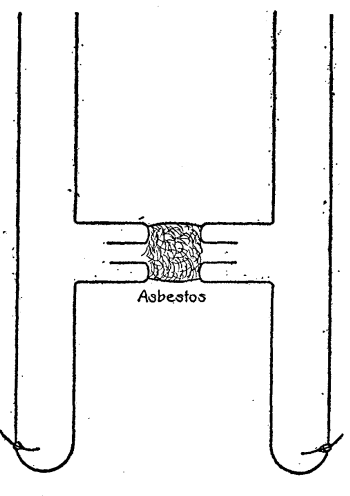

Fig. 4.

6 to $8 \mathrm{~cm}$. long and 0.5 to $1.0 \mathrm{~cm}$. in diameter. Place $B$ inside $A$ and insert in the ends of $A$ tight-fitting corks $C$ through which pass the small tubes $D$ one of which is open, the other sealed. Adjust the lengths of the tubes $D$ so that they enter $B$ just enough to hold it co-axial with $A$. The whole is held horizontally and is rotated in the small pointed flame of a blowpipe - or better in the flames of two blowpipes pointing into one another. The tube $A$ is melted 
in a narrow band nearly opposite the middle of $B$. At this point $A$ adheres to $B$ and after the tubes are thoroughly fused together they are blown out. While the tube is still warm the platinum wire $E_{1}$ is fused in above the bulb of the cell, in the usual manner. The corks are now withdrawn and one end of the cell is sealed and another platinum wire $E_{2}$ fused into it. With a little practice the cell can be constructed in less time than it takes to make an $\mathrm{H}$-form of cell.

The cell now appears as in Fig. 2. If it is to be used in a water thermostat, it may be placed in a test-tube containing an oil such as kerosene, to prevent short-circuiting; or the wire $E_{1}$ may be replaced by another sealed into a small tube which may pass through a cork above or may be sealed into the cell 5 or $6 \mathrm{~cm}$. above the bulb $F$ and pass down inside to a point just above $F$.

The cell is filled as follows :

Put mercury in the bottom of the tube by means of a small pipette or funnel made by drawing out a test-tube. Above this place the mercurous sulphate paste and cadmium sulphate crystals by means of a small tube. Then by means of a pipette put into the cell sufficient saturated cadmium sulphate solution to fill the bulb $F$. Air will thus be entrapped below $F$, and to remove it apply suction at the end of the cell. On removing the suction the solution will rush down to fill the space below the bulb. Now press some asbestos or glass-wool down through the inside tube to fill the bulb $F$, packing it in fairly tightly, yet not so compactly as to make the internal resistance of the cell too great. Then put enough cadmium amalgam in the space above $F$ to cover the platinum wire $E_{1}$ completely. Above this place cadmium sulphate crystals and add enough saturated cadmium sulphate solution to fill the cell about a centimeter above the end of the inside tube. 'Several centimeters above this, seal up the tube or insert a cork and the cell is completed as represented in Fig. 3. The Clark cell may of course be set up in the same way.

It is impossible to mix the contents of the anode and cathode compartments. If the cell is turned over the mercury runs down and is caught below the bulb, and when the tube is placed erect again the mercury returns to its original position. The amalgam, if 
it moves at all, will behave in a similar manner. If any mercury or amalgam or mercurous sulphate falls into either end of the inside tube, the asbestos in the bulb will prevent it from going into the other compartment.

The $\mathrm{H}$-form of cell is made transportable by employing a similar "double-trap" in the cross-tube connecting the two legs, as shown in Fig. 4. In this case the asbestos should be put into the bulb before the cross-tube is sealed to the legs.

Some cells like the above were made during the past year in the laboratory of physical chemistry, Princeton University, while working under the direction of Dr. Hulett on the subject of standard cells, in fact this cell is a modification of a form suggested by Dr. Hulett. Transportation and rough treatment have not caused the contents of the two compartments of these cells to mix in the slightest degree.

Dominion Astronomical ObServatory, OTtaWA, October, 1907. 